\title{
Domenico Felice - Davide Monda, Montesquieu. Intelligenza politica per il mondo contemporaneo
}

\section{Simón Gallegos Gabilondo}

\section{(2) OpenEdition}

1 Journals

\section{Edizione digitale}

URL: http://journals.openedition.org/studifrancesi/2159

DOI: 10.4000/studifrancesi.2159

ISSN: 2421-5856

\section{Editore}

Rosenberg \& Sellier

\section{Edizione cartacea}

Data di pubblicazione: 1 aprile 2014

Paginazione: 145

ISSN: 0039-2944

\section{Notizia bibliografica digitale}

Simón Gallegos Gabilondo, « Domenico Felice - Davide Monda, Montesquieu. Intelligenza politica per il mondo contemporaneo », Studi Francesi [Online], 172 (LVIII | I) | 2014, online dal 01 avril 2014, consultato il 18 septembre 2020. URL : http://journals.openedition.org/studifrancesi/2159; DOI : https://doi.org/10.4000/studifrancesi.2159

Questo documento è stato generato automaticamente il 18 settembre 2020.

\section{(c)}

Studi Francesi è distribuita con Licenza Creative Commons Attribuzione - Non commerciale - Non opere derivate 4.0 Internazionale. 


\section{Domenico Felice - Davide Monda,} Montesquieu. Intelligenza politica per il mondo contemporaneo

Simón Gallegos Gabilondo 


\section{NOTIZIA}

DOMENICO FELICE - DAVIDE MONDA, Montesquieu. Intelligenza politica per il mondo contemporaneo, Napoli, Liguori, 2012, pp. 334.

1 Volto a rilevare la fecondità e l'attualità del pensiero di Montesquieu, lo studio messo a punto da Domenico Felice e Davide Monda è lontano da una certa corrente interpretativa del filosofo francese che ne fa il difensore di un pensiero superato ma che soprattutto rischia di ridurlo ideologicamente ad autore d'Ancien régime. Queste pagine, facendo luce sul debito della cultura giuridico-filosofica occidentale alla sua opera, fanno apparire invece le ragioni per le quali molte idee che abitano il nostro pensiero trovano proprio in Montesquieu la loro origine, così come le regole fondanti presso geografie tra di loro così lontane. Se si tratta dunque di un moralista, allora lo è nel senso più elevato, dal suo alto ruolo di fondatore della scienza politica.

2 La prima parte del libro contiene due saggi: L'attualità inattuale di un protagonista della civiltà moderna e contemporanea (pp. 3-23) e Verso una fenomenologia invincibile del dispotismo (pp. 24-119). La seconda contiene una scelta di testi d'interpreti di rilievo del XIX e XX secolo: A.-F. Villemain, Elogio di Montesquieu (pp. 123-156); Ch.-A. Sainte Beuve, Montesquieu (pp. 157-200); F. Sclopis di Salerano, Considerazioni generali sull'“Esprit des lois" (pp. 201-222); E. Faguet, Montesquieu moralista politico (pp. 223-232); F. Strowski, Montesquieu (pp. 233-265); J. Dedieu, Montesquieu sociologo; Montesquieu riformatore (pp. 266-298); M. A. Cattaneo, Montesquieu e la repubblica federativa (pp. 299-309); S. Cotta, Intervista su Montesquieu (pp. 310-326). 